


\title{
PEQUENA HISTÓRIA CRÍTICA DOS VIADUTOS NA CIDADE BRASILEIRA ${ }^{1}$
}

\author{
A LITTLE CRITICAL HISTORY ABOUT THE VIADUCTS \\ IN BRAZILIAN CITY
}

\author{
Alícia Duarte Penna² \\ Marina Beatriz Tello Oliveira ${ }^{3}$
}

\begin{abstract}
Resumo
Trata-se de discutir o que mudou e o que se repete na história da produção e da apropriação dos viadutos nas cidades brasileiras. Como objeto de estudo, tomam-se os viadutos sobre a Via Expressa Leste-Oeste, em Belo Horizonte, Minas Gerais. Aberta em 1978, mediante uma operação de desfavelamento que envolveu a retirada de mais de 10 mil pessoas, essa via é recortada por uma trama de viadutos e passarelas que voltam a ser ocupados pela população de rua já no final da década de 1980. No início do século XXI, essa população é retirada dali pela Prefeitura Municipal de Belo Horizonte, os vãos sob os viadutos são aterrados, e placas com os dizeres "Área Pública: não ocupe" e "Denuncie ocupações irregulares" são instaladas em suas imediações. Uma história que retrata o paradoxo acusado por Flávio Villaça na trajetória do planejamento urbano do Brasil, que, desde a década de 1930, insere-se não mais na esfera política, mas na esfera da ideologia. Da cidade feia, mas passível de embelezamento, passa-se à cidade caótica eficiente; restou apenas uma cidade em que a pobreza não deve ser, em absoluto, visível.
\end{abstract}

Palavras-chave: Viadutos; Apropriação de espaços; Requalificação urbana; Políticas habitacionais; Direito à moradia.

\begin{abstract}
This article discusses what has changed and what is repeated in the history of the production and ownership of the viaducts in the Brazilian cities. As study object, take up the viaducts on the East-West Expressway in Belo Horizonte, Minas Gerais. Opened in 1978, through a operation of urbanization that involving the removal of over 10,000 people, this path is crossed by a network of viaducts and walkways that are again occupied by the homeless population at the end of the 80s. At the beginning of the century XXI this population is taken away by the Belo Horizonte city hall, the gaps under the viaducts are grounded, and signs that read: "Public Area: not occupy" and "Report illegal occupation" are installed in their vicinity. A story that portrays the paradox accused by Flávio Villaça in the path of urban planning in Brazil, since the 30s, no longer fits into the political sphere, but in the sphere of ideology. The ugly city, but subject to embellishment, goes to the chaotic city efficiently, there was only one city in that poverty should not be at all visible.
\end{abstract}

Keywords: Viaducts, spaces appropriation, urban renewal, housing policy, housing rights. 